\title{
Fostering the employability of business studies graduates
}

\author{
Shairn Hollis-Turner
}

\begin{abstract}
Higher education is under pressure to enhance the employability of graduates by ensuring that they acquire competencies that make them employable in the labour market. This research project investigated the contribution of higher education towards the employability of graduates within a business diploma programme. A Delphi approach was employed with the Delphi panel consisting of three types of professionals - employers within the corporate sector, academics in the field of business studies, and graduates with workplace experience in the corporate sector. Both quantitative and qualitative data were obtained from three rounds of surveys. The findings show that disciplinary knowledge of Information Administration, Business Administration, Communication and Personnel Management, and the simulation of workplace practices as well as work-integrated learning opportunities are significant to enhancing the employability of office administrators and office managers. These findings provided academics with the opportunity to make improvements to the curriculum to foster the employability of the graduates.
\end{abstract}

\section{Introduction}

There is growing pressure on higher education to heighten the employability of graduates by guaranteeing that the learning experiences of students contribute to instilling the attributes, knowledge and skills that will empower graduates to "perform successfully as citizens in the knowledge economy" (Nel and Neale-Shutte, 2013, p.437). South Africa is still grappling with developing its economy and also bringing restitution to its black population. The latest unemployment statistics measuring the number of individuals actively seeking employment as a percentage of the workforce shows that the unemployment rate in South Africa increased to $25.5 \%$ in the second quarter of 2014 (Statistics South Africa, 2014).

Higher education internationally, as well as in South Africa (e.g. Department of Education [DoE], 1997, 2002a, 2002b), has emphasised the need for increased graduate employability. Higher education reports such as the Robbins Report (1963), the Finn Committee (1991), the Mayer Committee 
(1992), the Dearing Report (1997), the DeSeCo Project (Organisation for Economic Co-operation and Development [OECD], 2001), the Report on Employability Skills for Australian Industry (Curtis and McKenzie, 2002); REFLEX Project (Allen and Van der Velden, 2007) and Confederation of British Industry (CBI) Universities UK Report (2009), all emphasise the role of the education and training sectors in preparing graduates to confront the challenges of a global knowledge-based economy.

Employability is seen as a symptom of the brisk changes related to globalisation, the liberalisation of trade, developments in information technology, biosciences, new materials and nanotechnology that have fuelled the rise of the "knowledge economy" (Davidson, 2007, p.1184). This together with technological advances and global economic dynamics requires that graduates have higher levels of knowledge and skills (Nel and Neale-Schutte, 2013). The education policy in South Africa has been intensely influenced by the global mandate that higher education institutions become more receptive to the needs and expectations of industry, the state and society, to guarantee economic and social success (Kruss, 2002). The curricular process provided by higher education attempts to facilitate the development of workplace prerequisites and to meet the demands of the knowledge economy by introducing work integrated learning projects, job shadowing and internships (Lowden, Hall, Elliot and Lewin, 2011, p.25) to name but a few examples. However, it cannot be assumed that the experience provided either by higher education, or in the workplace, or the fact that a student has completed a vocational course, will somehow ensure employability.

The study on which this paper is based argues that employability is about the development of critical, reflective graduates who are empowered to contribute to their future places of employment in order to retain employment and promotion prospects in an ever-changing competitive global society. In order to determine why so many of the graduates of a higher education programme are unemployed, it is necessary to look at the knowledge bases of the curriculum. Knowledge matters and therefore the knowledge bases selected for professional curricula can be expected to play a significant role in enhancing the employability of graduates. Young and Muller (2014) argue that in an age where there is a proliferation of expert occupations, the knowledge that underpins the professional curriculum is of particular significance. 
In this respect the study on which this paper is based broadly investigated the contribution of higher education towards the employability of graduates. The research objectives aimed to investigate the knowledge bases of current office management work expertise and the implications thereof for the training of office managers. The findings of this research project provided academics with the opportunity to make improvements to the curriculum and it provided guidelines for the recurriculation of the higher education programme in office management in accordance with the new qualifications framework of the Department of Education (2007).

\section{Literature review}

Universities often make a "wish list" (Barrie, 2006, p.215) of knowledge, skills and attributes that will supposedly foster the employability of graduates. Mason, Williams and Cranmer (2006) argue that from the viewpoint of employers, employability often refers to work readiness, described as the possession of attitudes, knowledge, skills, and commercial understanding enabling contributions to be made to the achieving of organisational goals after starting employment. It is also defined as the possession of "foundational skills needed to be minimally qualified for a specific occupation" (ACT, 2013, p.3).

Yorke and Knight (2006) identified four broad attainments on which employability is dependent, namely, knowledge and understanding; general and specific skills; efficacy beliefs and values; and metacognitive understanding. In educational research this position has remained dominant although it has been critiqued for neglecting other factors influencing employability. Contrary arguments include the work of McQuaid, Green and Danson who argue that a broader approach is necessary as it facilitates the "additional consideration of vital demand, personal circumstances and other factors that influence the employability of people in a particular labour market, or at a particular time" $(2005$, p.194).

McQuaid and Lindsay (2005) argue that employability is not simply about building the attributes and skills of students by educational organisations as such skills require support of knowledge of job seeking skills and are influenced by health factors, gender, age and mobility. Côté and Bynner (2008) argue that economic conditions may influence the social status of young individuals and subsequently their employability, while McGrath 
(2009) recognises that factors such as geographic location influence employability. Harvey and contributors (2003) contend that employability should be recognised as a process requiring more than the attributes, skills or experience to empower a student to get a job or to advance progress. The subject discipline selected by the graduate impacts to some degree on the opportunities for employability development. For example, involvement in employability development is considered easier for students studying professional programmes. However, "vocationalism is not synonymous with employability” (Harvey, 2002, p.5).

In the South African context, the Education White Paper 3: A curriculum for the transformation of higher education (DoE, 1997) described the role of higher education institutions as the mobilisation of human resource development. Graduate employability has therefore become a significant aspect of planning by institutional and academic forums since it is beneficial to higher education, employers and graduates' acquisition of an improved understanding of the causes of unemployable graduates (Nel and NealeShutte, 2013).

\section{Background to the study}

The focus of this research project is the employability of the graduates of a higher education programme at a University of Technology (UoT). The UoT comprises five faculties with over 32000 students. UoT's curricula have had a strong heritage in the provision of career-oriented education and focus on the workplace as both a learning resource and a site of knowledge production. In accordance with the National Plan for Higher Education (Ministry of Education, 2001) the assumption is that the primary focus of the UoT will be the cultivation of applied knowledge and job-related skills driven by market forces and entrepreneurialism (Imenda, 2005). Wheelahan (2010, p.4) argues that the purpose of professional and vocational education "is to induct students into a field of practice" and provide the knowledge that underpins practice.

The three-year higher education business programme on office management aims to provide the local and international corporate sector with graduates who are skilled in management, administration and technology. The curricular arrangement for office management studies comprises the work of the profession of office administration in support of people in a range of different 
industries. Students are required to study the two major disciplines of Information Administration (which comprises computer theory and practice) and Business Administration for the period of three years. The programme for office managers includes two years study of Communication and one year of Legal Practice, Personnel Management, Mercantile Law, Financial Accounting and six months of experiential training or work-integrated learning in the workplace. Graduates of the programme find positions of employment in a variety of fields in the business world such as personal assistant, administrative office manager, data processor, office administrator at a hospital, and administrative assistant in a personnel department or the accountancy/legal section of an organisation or legal firm. There are approximately 290 students studying either on a full-time or part-time basis.

Work experience alone does not ensure that graduates develop the "cognitive, social, practical. . . prerequisites" for employment (Yorke, 2004, p.7).

Similarly, the curricular process does not guarantee employability, but it may facilitate it (Knight and Yorke, 2004). The programme for office management attempts to facilitate employability by providing opportunities for work experience and by bringing practitioners and employers into the classroom. Students are required to take part in group work exercises and presentations, co-ordinate seminars, participate in one week volunteer placements in the workplace during the first and second year, as well as undertake six months internship in the third year of study.

\section{Research methodology}

This study draws on a Delphi approach which is an established method used to harness the opinions of a diverse group of experts (Powell, 2003). The research project on which this paper is based expanded on the Delphi method by reviewing the traditional Delphi view of 'expert', as the Delphi panel of experts included not only employers, but also graduates of the office management curriculum. It comprised the distribution of three rounds of surveys to a panel of professionals comprising employers, graduates and academics. This provided the opportunity for the testing of knowledge and learning by the professionals as they refined their opinions and reached consensus. The reasons for selecting this research method was to gain the input from the panel regarding the critical skills, generic attributes and discipline specific content which they considered as key to fostering the employability of the graduates. The researcher attempted to elicit judgements 
from the participants on the basis of surveys and focus group meetings, interviews and student surveys which centred on the research questions. For the purpose of this article only the primary data, both numeric and textual, obtained by using three rounds of Delphi surveys on the discipline specific content, is discussed.

Purposive sampling was used for the selection of the Delphi panel and provided in-depth information from an interested group of participants. Twenty-three business professionals, fifteen graduates and fifteen academics agreed to serve on the Delphi panel and participate in the three rounds of surveys over a period of three years. The selection criteria for the business experts, graduates and academics were as follows:

- $\quad$ business experts in the Western Cape who operated in local and international medium to high technological environments,

- business experts who were co-operative partners of the UoT,

- $\quad$ business experts who had employed or currently employ OM graduates and/or third-year students (interns) and who are directly involved in their selection and mentorship,

- $\quad$ graduates who had been employed for a minimum period of three years and who were currently in supervisory and/or office management practitioner positions,

- business experts and graduates who were involved in the major sectors of tourism, medical fields, service and retail industries, education, production, government and local government,

- those who spoke various South African first languages (e.g. isiXhosa, English, isiZulu and Afrikaans),

- $\quad$ academics employed in the workplace within the past two to four years where they held positions in the workplace such as accountant, management consultant, administrative officer, training consultant, operations manager and office managers, and

- academics who participated in regular meetings with the business sector to remain informed of the field of office administration and office management. 
The strict adherence to these selection criteria enabled participants to evaluate current office management work practices objectively to determine the knowledge areas of the curriculum required by office administrators and office managers. Relevant ethical considerations of anonymity were also considered for this research project.

The first round survey included the discipline specific content of the higher education programme. The panel was asked to rate the content of each discipline of the three year programme according to which were necessary, essential or critical to foster the employability of the graduate. They were also given the opportunity to list additional skills and knowledge areas omitted in the first round survey. The additional items were then added to the second survey and sent to the panel for rating. The data from the final round survey was analysed and an average of the ratings from each group of the Delphi panel was calculated to determine the overall consensus percentage. This data was analysed by examining the responses to the discipline specific ratings of Information Administration, Business Administration, Communication, Personnel Management, Financial Accounting and Legal Practice.

\section{Findings}

The findings are hierarchically ordered in line with the credit allocation of the disciplines of the office management programme.

\section{Information administration}

The findings showed that the MS Office suite (81\%) received the highest degree of consensus followed by word processing (74\%), emails and the internet (68\%), Spreadsheets: Excel (57\%), the protection of documentation $(57 \%)$ with the rest of the content of the Information Administration curricula receiving below $50 \%$ consensus.

The additional items added to the first round survey by graduates were the need for advanced Excel skills and the ability to identify different types of hardware or software and computer security threats. The data from the final round survey showed that the need for advanced skills on Excel received 40\% consensus of the panel and the ability to identify different types of hardware 
or software and computer security threats received $27 \%$ consensus of the panel. These findings imply that most of the panel did not have the same needs for graduates to have these skills. Many large organisations have Information and Technology support staff who would be responsible for the hardware or software installation and have qualified staff with advanced skills in Excel. While the knowledge of computer security and back-up procedures are necessary, these can be learned on site and often are particular to specific organisations.

Information and Communication Technologies (ICT) are considered essential to fostering the employability of graduates (Lowden et al., 2011). The International British Education and Examination Board (Edexcel) in its report on the global perspective of effective education for employment (Playfoot and Hall, 2009, p.50) identified one of the qualiies most valued by employers in South Africa as being that of a willingness to "embrace technology".

In the South African context there is a significant gap between what graduates bring to the workplace and employers' expectations in terms of ICT skills, with the biggest gap relating to the "ability to find and access information" (Griesel and Parker, 2009, p.11). The UKCES report entitled "The Employability Challenge" regards employability skills as those which must be present to empower an individual to apply the more particular knowledge and technical skills that their specific workplaces will expect and "using information technologies effectively - operating a computer, both using basic systems and also learning other applications as necessary" (2009, p.6). Refer to Table 1 below for the detailed results. 
Table 1: Information administration

\begin{tabular}{|l|c|}
\hline \multicolumn{1}{|c|}{ Infomation administration } & Consensus \\
\hline MS Office suite & $81 \%$ \\
\hline Word processing & $74 \%$ \\
\hline Emails and the Internet & $68 \%$ \\
\hline Spreadsheets: Excel & $57 \%$ \\
\hline Protection of documentation & $57 \%$ \\
\hline Windows management & $44 \%$ \\
\hline MS PowerPoint: Advanced & $41 \%$ \\
\hline Advanced skills on Excel & $40 \%$ \\
\hline Computer security & $39 \%$ \\
\hline Back-up procedures and software & $36 \%$ \\
\hline Flow of information & $36 \%$ \\
\hline Management of information technology and systems & $30 \%$ \\
\hline Structuring a document management system & $29 \%$ \\
\hline Management decision-making & $29 \%$ \\
\hline $\begin{array}{l}\text { Ability to identify different types of hardware or software and computer } \\
\text { security threats }\end{array}$ & $27 \%$ \\
\hline Risk management: internet and network security & $27 \%$ \\
\hline Production 35wpm & \\
\hline
\end{tabular}

While the importance of Information Administration skills for the fostering of the employability of office administrators and office managers cannot be denied, the challenge is to ensure that graduates are prepared for the technological demands of the varied fields in which they find employment. The field of information technology is constantly changing and it is required of higher education to not only keep up with business practices, but to ensure that graduates are taking innovative ICT knowledge into their future workplaces (Boud and Solomon, 2001; Geisler, Bazerman, Doheny-Farina, Gurak, Haas, Johnson-Eilola, Kaufer, Lunsford, Miller, Winsor and Yates, 2001; Barnett, 2004). This was supported by the opinions of a number of the employers and graduates on the Delphi panel. For example a graduate 
commented, 'having knowledge alone is not enough' and 'simulations of information technology skills will be useful'. This emphasises the need for academic staff to remain current with workplace practices so that they may make use of innovative methods to simulate these practices in the classroom to prepare students for the workplace (Jeong, Taylor and Chi, 2000).

\section{Business administration}

The highest rates of consensus of the Delphi panel were in respect of items added to the first survey, namely time management (89\%), and understanding the critical importance of administration as one of the pillars in any organisation $(73 \%)$. In the higher education context students are required to adhere to values of time management which mirror those of the workplace such as punctuality, the adherence to deadlines for the submission of tasks and assignments, and the presentation of written and oral feedback reports. The knowledge of administrative procedures $(73 \%)$ was followed by control of office activities (57\%) and an additional item, knowledge of company policies and procedures $(53 \%)$, which was added to the first round survey. Two other items added to the first survey were knowledge of planning, executing and reviewing events such as meetings and workshops, and project management. The rating of consensus of the Delphi panel for the significance of these areas of knowledge and skills was below $50 \%$.

Administration is considered essential in all sectors of business, regionally, nationally and internationally. In the South African context it is listed as a critical skill in the Education, Training and Development Practices (ETDP) Sector Education and Training Authority Report 2010/2011. A number of the employers and graduates called for increased simulation of workplace practices and an employer commented that 'the basic office management skills are necessary in all contexts' and 'should be applied in simulation exercises in the classroom'. This supports the view expressed earlier that students require opportunities to apply their knowledge in simulations of workplace practices. Table 2 shows the detailed results of the Delphi surveys. 
Table 2: Business administration

\begin{tabular}{|c|c|}
\hline Business administration & Consensus \\
\hline Time management & $89 \%$ \\
\hline $\begin{array}{l}\text { Understand the critical importance of administration as one of the pillars in any } \\
\text { oganisation }\end{array}$ & $73 \%$ \\
\hline Administrative procedures & $73 \%$ \\
\hline Control of office activities & $57 \%$ \\
\hline Knowledge of company policies and procedures & $53 \%$ \\
\hline The office: organisation and supervision & $49 \%$ \\
\hline Human resource management & $46 \%$ \\
\hline Evaluation of administrative systems & $44 \%$ \\
\hline $\begin{array}{l}\text { Knowledge of planning, executing and reviewing events such as meetings and } \\
\text { workshops }\end{array}$ & $42 \%$ \\
\hline Financial management & $42 \%$ \\
\hline Understand workplace safety and security issues & $37 \%$ \\
\hline Management functions & $36 \%$ \\
\hline Strategic management & $29 \%$ \\
\hline Project management & $29 \%$ \\
\hline Risk management & $27 \%$ \\
\hline Systems design and analysis & $24 \%$ \\
\hline Marketing and research & $22 \%$ \\
\hline Entrepreneurship & $20 \%$ \\
\hline Business sectors & $20 \%$ \\
\hline
\end{tabular}

\section{Communication}

The highest consensus ratings for the content of the Communication studies were for items added to the first round survey. Correct written language (77\%); understanding English language and the application of language skills (71\%), and documentation etiquette $(71 \%)$. This was followed by teamwork and small groups (70\%), listening skills and conflict resolution (64\%); oral communication and presentation skills (63\%), and the importance of setting goals and objectives (50\%). The rest of the content received less than 50\% 
consensus as being significant to fostering the employability of the graduate. The implications of these findings are that an excessive amount of time is spent in the classroom on the study and practice of written communication skills such as report writing (33\%), whereas employers pointed out that 'workplaces often have their own on-line reporting programmes'. The majority of the graduates and employers suggested that workplace simulations of communication situations should take place in the classroom. Refer to Table 3 below for the details.

Table 3: Communication

\begin{tabular}{|l|c|}
\hline \multicolumn{1}{|c|}{ Communication } & Consensus \\
\hline Correct written language & $77 \%$ \\
\hline Understanding English language and the application of language skills & $71 \%$ \\
\hline Documentation etiquette & $71 \%$ \\
\hline Teamwork and small groups & $70 \%$ \\
\hline Listening skills and conflict resolution & $64 \%$ \\
\hline Oral communication and presentation skills & $63 \%$ \\
\hline Goals and objectives & $50 \%$ \\
\hline Telephone technique & $45 \%$ \\
\hline Business letters: letters of complaint, enquiry, invitation, thanks, etc. & $43 \%$ \\
\hline Emails and facsimiles & $42 \%$ \\
\hline Proficiency in at least two official languages & $42 \%$ \\
\hline Meeting correspondence: notice, agenda, minutes & $38 \%$ \\
\hline CV writing and interview skills & $35 \%$ \\
\hline Report writing & $33 \%$ \\
\hline Intercultural communication & $32 \%$ \\
\hline Organisational communicaion & $32 \%$ \\
\hline Proposals & $32 \%$ \\
\hline Professional self-development & $31 \%$ \\
\hline $\begin{array}{l}\text { Website communication - Facebook, Twitter and other digital forms of } \\
\text { communication }\end{array}$ & $29 \%$ \\
\hline Research: referencing skills & $29 \%$ \\
\hline & \\
\hline
\end{tabular}


The UK Commission's Employer Skills Survey, 2013 (UK Commission for Employment and Skills, 2014) found an increase in skill-shortage vacancies as a result of a lack of communication skills, particularly oral communication, as well as a lack of literacy skills. Opportunities for deliberate practice and feedback on performance are necessary for the development of expertise in oral and writing skills, especially in the context of a "professionally relevant task domain" (Kellogg, 2008, p.18). For example, the Delphi graduates' comments were that the communication studies should include 'more presentation skills' and that 'communication skills are important and simulations of these skills will be useful'. Employers commented that 'communication knowledge and skills are particularly necessary among second- and third-language English speakers, working in a predominantly English environment' and 'technical knowledge and skills ... stand for little and are useless unless this can be communicated effectively and applied' .

\section{Personnel management}

One of the items added to the first round survey relating to significance of upholding confidentiality $(80 \%)$ received the highest consensus rating of the Delphi Panel. This was followed by knowledge of dealing with individuals (77\%), attitudes and behaviour in the workplace (62\%), understanding of organisational culture (61\%) which was also added to the first round survey, stress management (54\%), personal relationships on the job (52\%), and knowledge of labour laws and disciplinary procedures (50\%). Emotional intelligence and the importance of personal development were also added to the first round survey but both received less than $50 \%$ consensus rating from the Delphi panel. Refer to Table 4 for the detailed results. 
Table 4: Personal management

\begin{tabular}{|l|c|}
\hline \multicolumn{1}{|c|}{ Personnel management } & Consensus \\
\hline Upholding confidentiality & $80 \%$ \\
\hline Dealing with individuals & $77 \%$ \\
\hline Attitudes and behaviour in the workplace & $62 \%$ \\
\hline Understanding of organisational culture & $61 \%$ \\
\hline Stress management & $54 \%$ \\
\hline Personal relationships on the job & $52 \%$ \\
\hline Knowledge of labour laws and disciplinary procedures & $50 \%$ \\
\hline Emotional intelligence & $47 \%$ \\
\hline Personal development & $45 \%$ \\
\hline Resolving frustration and conflict & $43 \%$ \\
\hline Business psychology and human behaviour & $42 \%$ \\
\hline Dealing with small groups & $37 \%$ \\
\hline Human resource management: introduction & $30 \%$ \\
\hline Social and personal perception & $30 \%$ \\
\hline
\end{tabular}

Graduates need to know about dealing with individuals and group dynamics when they enter the workplace. An employer commented that 'being aware of how to deal with other people . . can only be developed through practice'. The UK Commission for Employment and Skills (2009, p.6) describes employability skills as including "working together - co-operating, being assertive, persuading, being responsible to others. ..".

\section{Financial accounting}

The highest consensus was received for budgets and budgetary control (60\%) and how to read a balance sheet and profit and loss accounts (56\%). The panel added items of legislation and financial policies and petty cash management, which received less than $50 \%$ consensus. Refer to Table 5 for the detailed results. 
Table 5: Financial accounting

\begin{tabular}{|l|c|}
\hline \multicolumn{1}{|c|}{ Financial accounting } & Consensus \\
\hline Budgets and budgetary control & $60 \%$ \\
\hline How to read a balance sheet and profit and loss accounts & $56 \%$ \\
\hline Results of operations and financial positions & $47 \%$ \\
\hline Introduction to accounting & $45 \%$ \\
\hline Legislation and financial policies & $45 \%$ \\
\hline Analysis and interpretation of financial statements & $42 \%$ \\
\hline Understanding monthly requisitions - to form part of budgets & $42 \%$ \\
\hline Petty cash management & $39 \%$ \\
\hline Income statement & $39 \%$ \\
\hline Stock & $37 \%$ \\
\hline Debtors & $36 \%$ \\
\hline Creditors & $36 \%$ \\
\hline Bank reconciliation statements & $31 \%$ \\
\hline Ledger and trial balance & $31 \%$ \\
\hline Fixed assets & $31 \%$ \\
\hline Cash flow management to balance sheet & $31 \%$ \\
\hline Subsidiary journals & $25 \%$ \\
\hline
\end{tabular}

A comment by an employer regarding the rating of items such as stock and debtors and creditors, was that 'one cannot do financial statements without these areas of knowledge and skills and therefore one cannot rate them as more or less important as the other'. A graduate commented that 'financial accounting skills are not critical for administrative work in the training environment - this function is outsourced' and an employer commented that 'apart from budget control and planning for the year ahead the financial management aspect is often based elsewhere as a support service'. Lowden et al. (2011, p.12) argue that employers "value numeracy relevant to the post".

The findings show that, while Financial Accounting knowledge and skills might be necessary for the employability of the graduates, many organisations have specialists who are responsible for these functions. Those graduates who 
find employment requiring these skills will have the basic financial knowledge and skills and can undertake further studies if required.

\section{Legal practice and mercantile law}

The highest consensus was for the additional area of knowledge of applicable legislation in the context of the working environment (68\%), which was added to the first round survey. Knowledge of labour law received 50\% consensus but $75 \%$ of the employers serving on the Delphi panel rated this knowledge as critical to the fostering of employability of graduates. Comments received from the graduates were that knowledge of their employment rights was beneficial, but it appears that most of the Delphi panel did not consider this content as critical to the employability of the graduates. The rest of the content received less than $50 \%$ consensus from the Delphi panel. Table 6 shows the detailed results of the Delphi survey.

Table 6: Legal practice and mercantile law

\begin{tabular}{|l|c|}
\hline \multicolumn{1}{|c|}{ Legal practice and mercantile law } & Consensus \\
\hline Knowledge of applicable legislation in the context of the working environment & $68 \%$ \\
\hline Labour law & $50 \%$ \\
\hline General principles of the law of contract & $43 \%$ \\
\hline Business law in order to be equipped to start own business & $43 \%$ \\
\hline Intellectual property: copyright, trademarks and patents & $32 \%$ \\
\hline Specific contracts & $28 \%$ \\
\hline The administration of justice & $24 \%$ \\
\hline Introduction to civil procedure and criminal litigation & $24 \%$ \\
\hline Introduction to the study of law & $20 \%$ \\
\hline Debt collection procedures in the Magistrate's Court & $20 \%$ \\
\hline
\end{tabular}

\section{Experiential training syllabus}

The members of the Delphi panel were selected as they are committed to and support the internship programme where students gain exposure to the world 
of work and receive mentorship from employers. Twice a year they have third-year students allocated to their organisations for the six months internship. This is learning combined with work and includes an organised programme merging applicable work experience with academic study. The practice of entering internships is a valuable training technique for learning skills as it unites observation, knowledge and action with learning from a mentor (Kellogg, 2008). Research undertaken in the UK on the employers' perceptions of the employability skills of new graduates (Lowden et al., 2011) recognised that internships, work placement and vacation work were effective to enhance graduate employability. This applied across all sectors and sizes of organisations and the duration of the experience of at least six months was considered necessary for students and employers to obtain the full benefits.

At a national level, the White Paper for Post-School Education and Training (DHET, 2013) emphasises the importance of close co-operation between employers and education providers, especially in professional curricula where on-the-job training, including internships, should be expanded upon. At the UoT at which the research was undertaken, an Advisory Committee is held twice a year comprising of graduates, and employers of the students undertaking the internship. This committee, of which most of the employers of the Delphi panel are members, plays a significant role in curricula development and to the fostering of the employability of graduates as they provide feedback on the programme content and make recommendations for changes to the curriculum where necessary.

\section{Conclusions}

These findings showed the relevance of the knowledge bases of the office management curriculum and identified what content needed to be added or omitted in order to foster employability and prepare students for the workplace. The discipline specific content considered key to the work readiness of the graduates with consensus ratings of $70 \%$ and higher showed the need for Information Administration knowledge of the MS Office suite and word processing; Business Administration knowledge of time management and the understanding of the critical importance of administrative procedures; Communication knowledge of the use of the correct written language, understanding of the English language and its application, documentation etiquette, and the ability to work in teams and 
small groups, and Personnel Management knowledge of the significance of upholding confidentiality and the ability to deal with individuals. The identification of the discipline specific knowledge considered key to the work readiness of the graduates by the Delphi panel provided academics with guidelines for improvements to the curriculum. The simulation of workplace practices and the provision of work-integrated learning opportunities are considered important for the training of office administrators and office managers and contribute to fostering the employability of office management graduates.

\section{References}

ACT Inc. 2013. Work readiness standards and benchmarks. http://www.act.org/newsroom/releases/view.php?lang=english\&p=2878[27 December 2014]

Allen, J. and Van der Velden, R. (Eds) 2007. The flexible professional in the knowledge society: general results of the REFLEX Project. Maastricht: Research Centre for Education and the Labour Market, Mastricht University.

Barnett, R.A. 2004. Learning for an unknown future. Higher Education Research and Development, 23(3): pp.247-260.

Barrie, S.C. 2006. Understanding what we mean by the generic attributes of graduates. Higher Education, 51(2): pp.215-241.

Boud, D. and Solomon, N. 2001. Work-based learning: a new higher education? Buckingham: Open University Press.

Confederation of British Industry (CBI); Universities UK. 2009. Future fit: preparing graduates for the world of work. London: $\mathrm{CBI}$.

Côté, J. and Bynner, J. 2008. Changes in the transition to adulthood in the UK and Canada: the role of structure and agency in emerging adulthood. Journal of Youth Studies, 11(3): pp.251-268.

Curtis, D. and McKenzie, P. 2002. Employability skills for Australian industry: literature review and framework development. Report to: Business 
Council of Australia; Australian Chamber of Commerce and Industry. Melbourne: Australian Council for Educational Research (ACER).

Davidson, M.R. 2007. Valuing employability: supervision training and the generic or transferable skills agenda. South African Journal of Higher Education, 21(8): pp.1184-1194.

Dearing, R. 1997. Report of the National Committee of Inquiry into Higher Education: Higher education in the learning society. London: HMSO.

Department of Education. 1997. Education White Paper No.3: A programme for the transformation of higher education. Government Gazette, 386(18207), 18 August 1997. (Notice No. 1196 of 1997). http://education.pwv.gov.za/content/documents/178.pdf [28 December 2014].

Department of Education. 2002a. A new academic policy for curricula and qualifications in higher education, 1 January 2002. Pretoria, South Africa: Department of Education.

http://education.pwv.gov.za/content/documents/251.pdf [28 December 2014].

Department of Education. 2002b. A new institutional landscape for higher education in South Africa, 30 May 2002. Pretoria: Department of Education. http://education.pwv.gov.za/content/documents/335.pdf [28 December 2014].

Department of Education. 2007. The higher education qualifications framework. Government Gazette, (30353), 5 October 2007. (Notice No. 928 of 2007).

Department of Higher Education and Training (DHET). 2013. White Paper for post-school education and training. Pretoria, South Africa: DHET. January.

Education, Training and Development Practices (ETDP). 2010. Sector education and training authority report: 2010/1011. Pretoria, South Africa: DHET.

Finn, B. 1991. Young people's participation in post-compulsory education and training: report of the Australian Council Review Committee. Canberra: Australian Government Publishing Service. 
Geisler, C., Bazerman, C., Doheny-Farina, S., Gurak, L., Haas, C., Johnson-Eilola, J., Kaufer, D.S., Lunsford, A., Miller, C.R., Winsor, D. and Yates, J. 2001. IText: future directions for research on the relationship between information technology and writing. Journal of Business and Technical Communication, 15(3): pp.269-308.

Griesel, H. and Parker, B. 2009. Graduate attributes: a baseline study on South African graduates from the perspective of employers. Pretoria: HESA; SAQA.

Harvey, L. 2002. Employability and diversity. www2.wlv.ac.uk/webteam/confs/socdiv/sdd-harvey-0602.doc [Unpublished MicrosoftWord document]. [10 November 2013].

Harvey, L. and contributors. 2003. Transitions from higher education to work. Sheffield: Centre for Research and Evaluation, Sheffield Hallam University. http://www.qualityresearchinternational.com/esecttools/esectpubs/harveytrans itions.pdf [27 December 2014].

Imenda, S.N. 2005. The idea of a South African university and implications for knowledge production. South African Journal of Higher Education, 19 (Special Issue): pp.1405-1418.

Jeong, H., Taylor, R. and Chi, M. 2000. Learning from a computer workplace simulation. Proceedings of the 22nd annual meeting of the Cognitive Science Society: 705-710, Mahwah, NJ: Lawrence Erlbaum Associates.

Kellogg, R.T. 2008. Training writing skills: A cognitive development perspective. Journal of Writing Research, 1(1): pp.1-26.

Knight, P.T. and Yorke, M. 2004. Employability through the syllabus. Tertiary Education and Management, 8(40): pp.261-276.

Kruss, G. 2002. Employment and employability: expectations of higher education responsiveness. Proceedings of the Council on Higher Education Colloquium: Building Relationships between Higher Education and the Private and Public Sectors. Sandton, 27-28 June 2002. Pretoria: CHE: pp.59-113. 
Lowden, K., Hall, S., Elliot, D. and Lewin, J. 2011. Employers' perceptions of the employability skills of new graduates. London: SCRE Centre, University of Glasgow, Edge Foundation.

Mason, G., Williams, G. and Cranmer, S. 2006. Employability skills initiatives in higher education: what effects do they have on graduate labour market outcomes? London: National Institute of Economic and Social Research, Institute of Education, University of London.

Mayer, E. 1992. Key competencies: Report of the committee to advise the Australian Education Council and Ministers of Vocational Education, Employment and Training on employment-related competencies for postcompulsory education and training. (Mayer report). Canberra: Australian Education Council (AEC); Ministers of Vocational Education, Employment and Training (MOVEET).

McGrath, S. 2009. What is employability? Learning to support employability. Project Paper No.1, Learning to Support Employability Project, University of Nottingham.

McQuaid, R.W., Green, A. and Danson, M. 2005. Introducing employability. Urban Studies, 42(2): pp.191-195.

McQuaid, R.W. and Lindsay, C. 2005. The concept of employability. Urban Studies, 42(2): pp.197-219.

Nel, H. and Neale-Shutte, M. 2013. Examining the evidence: graduate employability at NMMU. South African Journal of Higher Education, 27(2): pp.437-453.

Organisation for Economic Co-operation and Development (OECD). 2001. Competencies for the knowledge economy. In OECD Education policy analysis. Paris: OECD: pp.99-118. http://www.oecd.org/dataoecd/42/25/1842070.pdf [20 June 2013].

Playfoot, J. and Hall, R. 2009. Elective education for employment: a global perspective. A report commissioned by Edexcel and prepared by White Loop. April 2009. London: Edexcel, Pearson, White Loop. 
Powell, C. 2003. The Delphi technique: myths and realities. Journal of Advanced Nursing, 41(4): pp.376-382.

Robbins Report, The. 1963. [Great Britain. Committee on Higher Education. Higher Education: Report of the Committee Appointed by the Prime Minister, under the Chairmanship of Lord Robbins, 1961-1963]. London: Her Majesty's Stationery Office.

Ministry of Education. 2001. National plan for higher education. Pretoria, South Africa: Ministry of Education.

Statistics South Africa. 2014. South Africa unemployment rate 2000-2014. http://www.tradingeconomics.com/south-africa/unemployment-rate [29 July 2014].

UK Commission for Employment and Skills. 2009. The employability challenge. Employee demand for skills: a review of evidence and policyExecutive summary. February 2009.

UK Commission for Employment and Skills. 2014. UK Commission's employer skills survey 2013: UK results. January 2014.

Wheelahan, L. 2010. Why knowledge matters in curriculum: a social realist argument. London: Routledge.

Young, M. and Muller, J. (Eds). 2014. Knowledge, expertise and the professions. Abingdon: Routledge.

Yorke, M. 2004. Employability in Higher Education: what it is - what it is not. Learning and Employability Series One. York: Higher Education Academy.

Yorke, M. and P. Knight. 2006. Embedding employability into the curriculum. Learning and Employability Series One. York: Higher Education Academy.

Shairn Hollis-Turner

Cape Peninsula University of Technology

hollis-turner@,cput.ac.za 